\title{
The Use of Isophane Insulin for the Control of Diabetes Mellitus in Dogs
}

\author{
By F. Hjort Lorenzen.
}

Pharmaceuticals Division, Novo Nordisk A/S, Bagsværd, Denmark.

\begin{abstract}
Hjort Lorenzen, F.: The use of isophane insulin for the control of diabetes mellitus in dogs. Acta vet. scand. 1992, 33, 219-227. - For this study 54 dogs with diabetes mellitus verified by anamnesis, clinical examinations and laboratory analyses were selected in 13 Danish and Swedish small animal clinics. After instruction the owners gave isophane insulin ("Insulin Protaphan Human" ()) injections to the dogs morning and evening followed by a commercial or homemade meal rich in fibers. The veterinarians examined the treated dogs 5 times or more in the 90 day treatment period, preferably in the morning before injection and meal. In all 54 dogs the clinical symptoms disappeared a few days after isophane insulin injections, and $54 \%$ of the dogs were clinically healthy within 8 days. Within a month $96 \%$ of the dogs were normalized after therapy. Simultaneously the blood glucose levels were normalized in $64 \%$ of the dogs within 14 days and in further $21 \%$ within 30 days. The urine glucose levels were normalized in $64 \%$ of the dogs within 14 days and for further $19 \%$ within 30 days. At the end of the study 48 out of the 54 diabetic dogs were clinically healthy, alert and free from symptoms of diabetes. The average dose of isophane insulin was for greater dogs 0.44 units per kg bw twice a day, for small dogs 0.79 . Six dogs had been destroyed in the trial period for various reasons. One owner had injection troubles. Another owner was hospitalized and had to get rid of the dog. One dog developed advanced breast cancer, 1 went fierce and 2 developed cataracts. Four dogs had by 1 or 2 occasions shown hypoglycemic symptoms, which quickly disappeared after appropriate adjustments of insulin dosing, feeding schedule and exercise programme. It can be concluded that isophane insulin is a highly suitable insulin preparation for a 2 injection per day treatment of diabetic dogs.
\end{abstract}

canine diabetes mellitus; field trial; clinical efficacy and safety.

\section{Introduction}

Since the sixties it has been recommended to use longer-acting insulines for the treatment of diabetes in dogs (Gordon 1967). Withdrawal of some of the older insulin types from the markets offered an opportunity to evaluate some of the newer preparation types for the treatment of diabetic dogs.

In a preliminary unpublished study made by the author it was shown that the normal dog has elevated blood insulin (IRI) levels already 30 min after intake of a standard commercial meal (no. 4024 from Altromin International,
Germany), see Fig. 1. The levels had maximum after $1 \mathrm{~h}$, kept high the next $3 \mathrm{~h}$ and returned to baseline level at 6-8 $\mathrm{h}$.

In another study the dynamics of isophane insulin human in normal dogs were estimated (Fig. 2). When given at a dose of $0.5 \mathrm{IU}$ per $\mathrm{kg}$ body weight to fasting dogs the isophane insulin lowered the blood glucose to about half of the fasting level. The effect was seen from 30 min after injection, had its nadir at 2-4 $\mathrm{h}$ and disappeared $12 \mathrm{~h}$ later. Accordingly the insulin values were raised after 30 min after injection, peaked at $90 \mathrm{~min}$ and gradually declined 


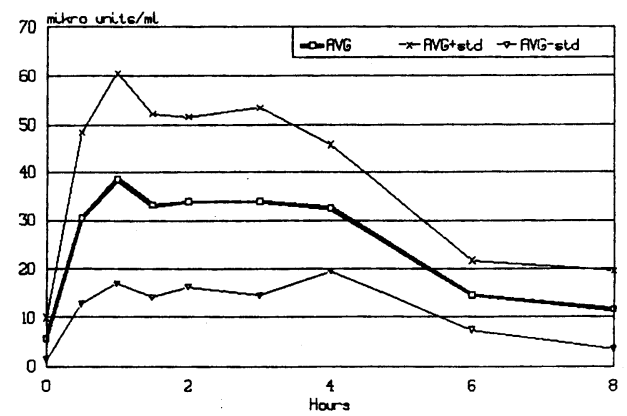

Figure 1. Postprandial plasma insulin levels in 8 normal dogs. (AVG = average, \pm std $= \pm$ standard deviation)

to baseline values at 8-12 $\mathrm{h}$ (Lorenzen 1987). This is in reasonable accordance with the kinetic profile of isophane insulin in normal dogs published by others (Goeders et al. 1987), who found a maximum insulin level at 41 min and a maximum glucose level reduction at 90-120 min after subcutaneous injection.

Under the assumption that the diabetic dog needs an insulin supply which mimics the above described postprandial insulin profile for the normal dog there were good reasons to believe that the isophane insulin will cover the need for insulin in the diabetic dog for around 12-14 h.

Several authors (Nelson 1989, Milne 1989, Lilley 1988, Feldman 1987, Milne 1987, Nelson 1985a, Nelson 1985b, Chastain 1984, Schaer 1983) have recommended the use of isophane- or zinc protamin insulines for the control of canine diabetes, mostly as 1 injection per day followed by a complex feeding program with 3-4 fractionated meals a day.

The dynamic profile of isophane insulin indicates that the diabetic dog by 1 injection per day in many cases will revert to the diabetic state the last hours before the next injection. A more optimal therapy along the principles

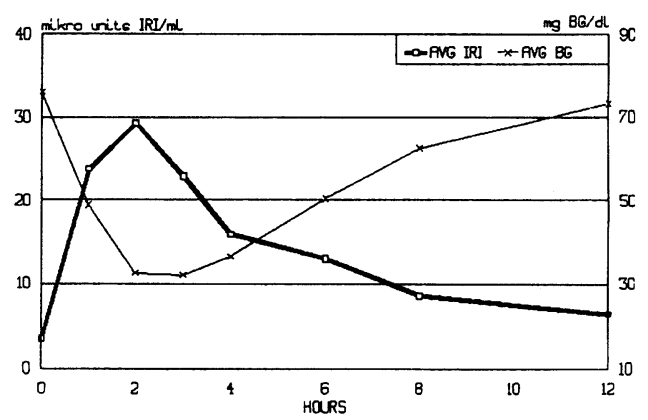

Figure 2. Mean (AVG) plasma insulin (IRI) and glucose (BG) levels after subcutaneous injection of 0.5 units of isophane insulin / $\mathrm{kg}$ bodyweight.

in modern human diabetes therapy comprise 2 injections per day, each time followed by a meal.

Therefore the aim of this study was to test the suitability of isophane insulin for diabetic dogs in a 2-injection-per-day dose regimen under field conditions in a 3 months treatment period.

\section{Materials and methods}

\section{Study design}

The project group established contact with 13 small animal veterinary clinics in Denmark and Sweden which had previous experience in the diagnosis, treatment and control of diabetes in dogs. The veterinarians randomly selected pairs of dogs and owners among the diagnosed cases of diabetes which they found fit for and interested in joining this study.

The owners got instruction from the investigators concerning the diagnosis, the use of laboratory sticks, the injection procedure, the dosing and the diet and exercise demands. Furthermore, the symptoms of hypoglycemia and subsequent treatment were explained. For the control of the treatment and adjustments of dose etc. the owners were asked to 
bring the dog before the morning injection and meal into the clinic at least 5 times within the next 3 months. It was preferred that the diabetic dog as fast as possible was controlled and dosed by the owner at home in its normal surroundings.

The isophane insulin treatment of the diabetic dog should within a couple of weeks relieve the clinical symptoms of diabetes, so that the dog appeared healthy and alert and had a normalized diuresis. Its fasting blood glucose level ought to be below $11 \mathrm{mmol} / \mathrm{l}$ and its urine glucose level below $56 \mathrm{mmol} / \mathrm{l}$.

\section{Selection of patients}

Anamnesis. A report from the owner on the observation of polydipsia, polyuria, loss of weight and fatigue during a couple of weeks were highly essential.

Clinical Examination. A thorough physical examination was emphazised, also for the detection of concominant diseases and exclusion of cases of secondary diabetes, see below. Laboratory analyses. Morning blood samples was tested for content of glucose (BG), either photometrically on a Reflotron ${ }^{\mathrm{R}}$ or Hypocount ${ }^{\mathrm{R}} \mathrm{MX}$ photometer or visually with BM Haemo Glucotest ${ }^{\mathrm{R}}$ 1-44 sticks. BG values had to be higher than $11 \mathrm{mmol} / \mathrm{L}$.

The morning urine was initially tested by the investigator with a Reflotron spectofotometer or with Ames ${ }^{\mathrm{R}}$ Multistix, later on with KetoDiabur $^{R} 5000$ stix. The owners were recommended to use Diabur 5000 stix. The urine should contain more than $56 \mathrm{mmol} / \mathrm{L}(1.0 \%)$ glucose, and no or moderate amounts of ketones and protein. The gravity should be normal or slightly elevated.

Exclusion criteria. Patients showing signs of acute or cronic nephritis, pyometra or hyperadrenocorticism had to be excluded from the study.
Furthermore, dogs in ketoacidotic coma, in oestrus, in systemic cortisone or depot progesteron treatment should not be included in the study.

The dog owners had to be motivated to join the study and have time and skill to do the injections, the urine sampling, feed the dog according to the instructions and exercise it regularly.

\section{Test preparation}

The test preparation used was "Insulin Protaphan Human R" from Novo Nordisk Ltd. with 100 units human isophane insulin per $\mathrm{ml}$. The preparation was delivered either as vials of $10 \mathrm{ml}$ and disposable syringes and needles or in $1.5 \mathrm{ml}$ prefilled syringes ("Novolet ${ }^{\circledR ")}$. The investigators were asked to instruct the owners to store the preparation in a standard refrigerator before use.

\section{Dosage}

The investigators were free to fix the individual insulin dose. We proposed that the great diabetic dog initially was injected with $0.3-0.4$ insulin units per $\mathrm{kg}$ body weight morning and evening $12 \mathrm{~h}$ apart and given the half day ration of food 10-15 min later. For smaller dogs a dose of 0.6-0.7 units per $\mathrm{kg}$ bw twice a day was proposed. The dose had to be injected subcutaneously in the neck just cranial to the scapular region. The veterinarians were asked to give the owners precise instructions in the handling of vials and syringes and the injection technique. A first trial with physiological saline was recommended.

The owners were instructed temporarily to halve the dose, if the dog became acutely febrile or underwent greater surgery.

\section{Diet and exercise}

The owners were asked to feed the dog with a rather uniform daily quantity of either com- 
mercial or homemade food which was rich in fibers and had a low content of easily digestible carbohydrates. Sweets, chocolate, sweet fruits etc. had to be avoided.

The dogs had to get an appropriate and constant deal of physical exercise every day.

\section{Side effects - hypoglycemia}

The owners were informed by the investigators about the symptoms of hypoglycemia (stupor, incoordinated gait, salivation, convulsions and unconsciousness). In case of hypoglycemia the owners were asked immediately to dose the dog perorally with 1-2 tablespoons of glucose ("Dextropur ${ }^{\circledR}$ ") dissolved in $1 / 4^{-1 / 2}$ cup of temperated water. If the symptoms did not disappear within 10-15 min the owner should contact the investigator. The episode and also other observed side effects to the treatment should be informed to the investigator and noted.

\section{Follow up procedures}

The investigators were asked to call the owners and their diabetic dog to the clinic in the morning (before injection and meal) on day 8 , $15,30,60$ and 90 approximately.

The investigators inquired the owner about changes in symptoms of diabetes, made physical examination of the dog and measured the contents of glucose in a blood and a urine sample, the latter perhaps collected by the owner. Based on the information obtained the investigators made appropriate adjustments in the treatment.

\section{Forms and records}

For the investigators' use a 2-page case report form was provided containing space for the clinical diagnosis, the laboratory results, the treatment and instructions given etc. At the end of the study the filled in forms were collected and sent to the author for evaluation. To ease the instruction of the owner a guide was prepared containing the clues of information concerning the diagnosis, the treatment, the diet and exercise, urine sampling, use of sticks and insulin dose adjustments and treatment of hypoglycemic episodes.

\section{Results}

\section{Initial consultation}

The clinics have reported on the examination, treatment, control and follow up on 54 diabetic dogs. Based on the information on the individual patient forms summary sheets were elaborated showing the type of dogs joining the study, symptoms of disease and laboratory results obtained. From these the following information is extracted:

Age, Weight, Sex and Breed. The dogs had an average age of 9.5 years at the initial consultation. The oldest dog was 14 and the youngest 4 years old (Fig. 3). The weights were between 3 and $50 \mathrm{~kg}, 28$ weighing $15 \mathrm{~kg}$ or more, 26 less than $15 \mathrm{~kg}$. Within these 15 dogs weighed 6-10 kg (Fig. 4).

Sixteen were males and 38 were females. Of the latter group 14 were sterilized, most of them operated at the initiation of the insulin treatment.

The distribution of breeds was: 10 labradors, 9 poodles, 6 crossbreeds, 5 dachs, 3 german shepherds, 2 white highlanders, 2 papillons, 2 samoyeds, 2 beagles, 1 pomeranian, 1 australian terrier, 1 schnauzer, 1 irish setter, 1 westi, 1 gordon setter, 1 english setter, 1 tiberian terrier, 1 cairn terrier, 1 bouvier, 1 norrbotton, 1 cocker spaniel and 1 birden collie.

Clinical symptoms. In 51 cases the owners reported that the dogs had had polydipsia and polyuria for a few days to several months, and 1 for around half a year. Weight loss were observed in 30 dogs. A general fatigue was seen in 28 dogs and 4 dogs had their diabetes diagnosed 1-3 years earlier and had been in zinc 


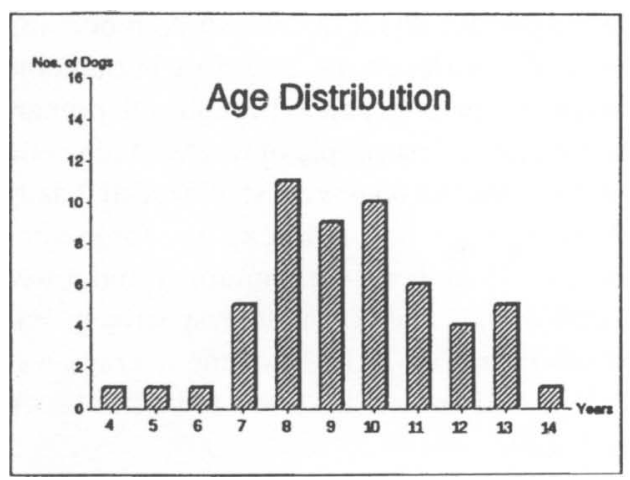

Figure 3: Age Distribution for 54 Diabetic Dogs.

protamin insulin treatment until joining this study.

Laboratory results. All the dogs had highly elevated blood glucose levels ranging from 11 to $44 \mathrm{mmol} / \mathrm{l}$ with a mode of 19 - 27 $\mathrm{mmol} / \mathrm{l}$. On $3 \mathrm{dogs} 47 \mathrm{mmol} / \mathrm{l}$ was measured. All the urine samples from the dogs contained glucose. Figures from 28 to more than 280 $\mathrm{mmol} / \mathrm{l}$ were measured, in 29 cases $>200$ $\mathrm{mmol} / \mathrm{l}$.

Ketones were found in the urine in 28 cases. Values from $+(0.5 \mathrm{mmol})$ to $+++(7-12$ $\mathrm{mmol} / \mathrm{l}$ ) were seen. Small to moderate amounts of protein were found in 21 dogs. The specific gravity of the urine specimens were measured in 46 cases and averaged 1.036 \pm 0.010 ranging from 1.004 to 1.060 .

Statistics have been omitted, since the individual raw data are created in 13 different small animal clinical laboratories, the procedures of which had not been intercalibrated.

The diagnosis. All the selected 54 dogs suffered definitively from diabetes mellitus, as they showed clinical symptoms and laboratory data characteristic for the disease. Furthermore, none of the dogs showed symptoms of acute or chronic nephritis, pyometra or adrenocortical hyperfunction. Two of the dogs had

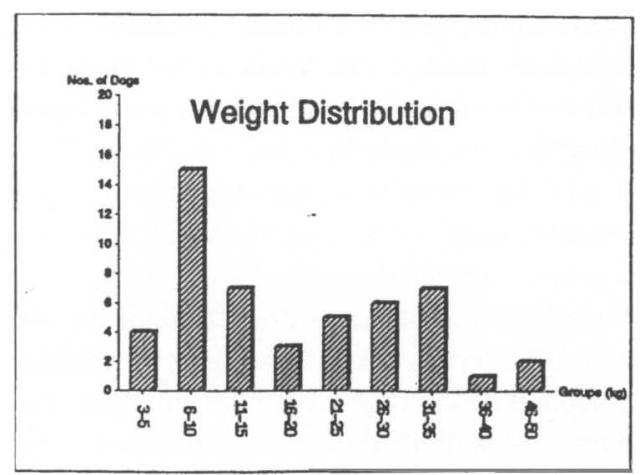

Figure. 4: Weight Distribution for 54 Diabetic Dogs.

been in systemic cortisone treatment for other diseases 1-2 months before the onset of diabetes, 3 cases had symptoms of fatty liver syndrome and 1 had a breast tumor.

Dosage. The veterinarians initially prescribed on average $0.47+/-0.09$ units of isophane insulin $/ \mathrm{kg}$ body weight for the greater dogs, 0.25 units being the minor and 0.62 the major dose used. For the smaller dogs the vets prescribed $0.61+/-0.20$ units $/ \mathrm{kg}$, however within a broader range ( 0.24 - 1.05 units). Other treatment. None of the dogs received any kind of other medication for their diabetes. Four dogs were treated with antibiotics, primarily for urinary infections.

\section{Follow up consultations}

As reported above the investigators were asked to make an examination of the diabetic dog around day 8, 15, 30, 60 and 90 for monitoring the response to the isophane insulin treatment. In general the veterinarians followed this instruction quite well, but as the whole study was set up as a field trial and on a voluntary base some omitments of control visits and lacks of notifications have been unavoidable. On the other hand some added more control visits to the programme. 
A part of the veterinarians supplemented this schedule with 1 day visits to the clinic for some of the dogs in order to make serial blood glucose measurements every 1 to $2 \mathrm{~h}$ for 10-14 $\mathrm{h}$ after the morning insulin injection, getting valuable data concerning the insulin responsiveness, optimal dose etc.

Fortyeight out of the 54 dogs fulfilled the isophane insulin treatment during the scheduled period. The average treatment time was 146 days, 384 and 15 days being the upper and lower range.

Clinical symptoms. Already within the first week of treatment the health of the dogs began to normalize.

The clinical symptoms of diabetes disappeared quite rapidly in the treated dogs. Already within 8 days treatment $54 \%$ of the dogs were normalized or at least markedly improved and within a month further $44 \%$ were clinically normalized. One dog had unchanged symtoms for 16 days, see section "Injection technique" below.

For 37 dogs the daily urine production had been estimated and noticed. Normuria was obtained in $46 \%$ of the dogs within 8 days, in further $24 \%$ in 2 weeks and in further $16 \%$ within a month.

Laboratory results. The blood glucose (BG) levels were lowered quite soon. Already within 8 days the levels were normalized for $32 \%$ of the dogs, within 14 days for further $32 \%$ and within a month for further $21 \%$. One dog had practically unchanged BG values in 16 days, see section "Injection technique".

The urine glucose (UG) levels were normalized in $38 \%$ of the dogs within 8 days, for further $26 \%$ within 2 weeks and for further $19 \%$ within 30 days. The levels remained unchanged for 2 dogs. For 2 other dogs UG testing was omitted until day 49 and 69 respectively, on which days the UG levels were normal.
Dosage. Based on the measured blood and urine glucose levels the daily dose of isophane insulin to the dogs had to be adjusted, primarly within the first couple of weeks. At the end of the study the dogs were stabilized at 2 daily doses of $0,44 \pm 0,13$ units $/ \mathrm{kg}$ b.w. for greater dogs ( $\geq 15 \mathrm{~kg}$ b.w.) with an upper and lower range of 0.77 and 0.26 units respectively. For smaller dogs $(<15 \mathrm{~kg}$ b.w.) the average was $0,79 \pm 0.32$ units / $\mathrm{kg}$ b.w. ranging between 0.40-1.87.

Injection technique. Most owners had adapted the injection techniques quite well, especially the Swedish dog owners who were provided with the prefilled syringes (the "Novolet"). One dog owner faced so great troubles of doing the injections so he gave up on day 16.

Diet. Thirtysix owners chose to use a commercial diet as the main food for their diabetic dog (in most cases "Prescription Diet"). A few changes from commercial to home made diets and visa versa were reported.

Side effects - hypoglycemia. Three dogs had at one occasion shown hypoglycemic symptoms after insulin injections (at day 13, 40 and 183 respectively). In the latter case the owner admitted to have given a double dose of insulin. The reactions disappeared quickly with oral glucose treatment and adjustments of dose and feeding. One dog showed transient hypoglycemic symptoms twice (around day 150), which were corrected as above, and the dog was quick and alert soon after and well regulated at the end of the study (day 160).

Concominant diseases. In the trial period 1 dog swallowed a foreign body but recovered within a week and continued on the insulin treatment. Another dog got a parvovirus enteritis at day 109 but was cured and put on isophane insulin treatment again. Three cases of cystitis were diagnosed and treated. 
Table 1. Recovery rates for diabetes mellitus in the treatment period.

\begin{tabular}{|c|c|c|c|c|c|}
\hline & \multicolumn{5}{|c|}{ Days from the initial consultation } \\
\hline & $3-8$ & $9-15$ & $16-30$ & $30-60$ & $61-90$ \\
\hline \multicolumn{6}{|l|}{$\begin{array}{l}\text { Clinical symptoms } \\
(\mathrm{n}=54)\end{array}$} \\
\hline Normalized/ & $54 \%$ & $+32 \%$ & $+11 \%$ & $+2 \%$ & \\
\hline \multicolumn{6}{|l|}{ Improved } \\
\hline Unchanged & $3 \%$ & & & & \\
\hline Normuria $(n=37)$ & $46 \%$ & $+24 \%$ & $+16 \%$ & $+8 \%$ & $+3 \%$ \\
\hline Unchanged polyuria & $3 \%$ & & & & \\
\hline \multicolumn{6}{|l|}{ BG - levels $(n=47)$} \\
\hline Normalized $^{1}$ ) & $32 \%$ & $+32 \%$ & $+21 \%$ & $+6 \%$ & \\
\hline Improved $^{2}$ ) & $2 \%$ & $+2 \%$ & $+2 \%$ & $+2 \%$ & \\
\hline Unchanged & $2 \%$ & & & & \\
\hline \multicolumn{6}{|l|}{ UG - levels $(n=47)$} \\
\hline Normalized ${ }^{3}$ ) & $38 \%$ & $+26 \%$ & $+19 \%$ & $+11 \%$ & \\
\hline Improved $^{4}$ ) & & $2 \%$ & & & \\
\hline Unchanged & & & & & $4 \%$ \\
\hline
\end{tabular}

$\mathrm{n}=$ number of dogs, for which valid information has been obtained.

1) "Normalized" means that BG levels have dropped to $\leq 11 \mathrm{mmol} / \mathrm{l}$.

2) "Improved" means that BG levels dropped to $\leq 15 \mathrm{mmol} / \mathrm{l}$ or $\leq 65 \%$ of the initial level.

3) "Normalized" means that UG levels dropped to $\leq 56 \mathrm{mmol} / \mathrm{l}$.

4) "Improved" means that UG levels dropped to $\leq 50 \%$ of initial level, but still $\geq 56 \mathrm{mmol} / \mathrm{l}$.

Drop outs. In the treatment period 6 dogs were put down for various reasons. One owner had injection procedure troubles and gave up day 16. One dog responsed well on the insulin treatment but was euthanized at day 15 as the owner was hospitalized. One dog developed advanced breast cancer and was destroyed on day 30 . One went fierce and was destroyed day 38 and two developed cataracts and were killed day 59 and 64 respectively.

\section{Discussion}

This report informs about a practical multi- center trial involving 13 small animal veterinary clinics. In the study period 54 dogs were treated with isophane insulin preparation to control their diabetes.

Based on the clinical findings and laboratory data there is no doubt that all the joining 54 dogs had diabetes mellitus at the initiation of the study. This was further confirmed by their good response to insulin treatment.

The implemented procedures for diagnosis of the disease follow the recommendations in scientific handbooks and publications on the subject. The dosage is, however, different, as 
Table $2:$ Number of hypoglycemic attacks and drop outs in the treatment period.

\begin{tabular}{|c|c|c|c|c|c|}
\hline & \multicolumn{5}{|c|}{ Days from the initial consultation } \\
\hline & $3-8$ & $9-15$ & $16-30$ & $30-60$ & $61-90$ \\
\hline Hypoglycemic attacks & & 1 & & 1 & 2 \\
\hline Bad regulation & & & 1 & & \\
\hline Owner illness & & 1 & & & \\
\hline Breast cancer & & & 1 & & \\
\hline Fierceness & & & & 1 & \\
\hline Cataracts & & & & & 2 \\
\hline
\end{tabular}

one normally find dosage regimens with 1 injection per day also for isophane insulins. The recommendation for the latter is, however, mostly based on human data.

Many efforts were made in the study to uniform the diagnosis, treatment and follow up in the individual clinics. In general, this has succeeded quite well, although omissions and lack of notifications were unavoidable. The effect of the treatment with isophane insulin might well be even better than described under "Results", if some of dogs had been examined more regular to schedule in the treatment period, especially within the first 2 weeks.

Some of the blood and urine parameters vary much, also for the individual dog. Many causes are possible, incorrect injections of the dog, wrong sampling time, inter- and intralaboratory procedure variations etc. Especially the urine glucose values are fluctuating.

The knowledge of the minute regulation of the urinary excretion of glucose in the dog is probably up to now too sparse to use this parameter as a standard main monitor of the accuracy of insulin dosing.

When in oestrus and dioestrus the female dog seems difficult to regulate. It seems advisable to sterilize the female dog, if a proper constant regulation is wanted, a recommandation emphasized by others (Holm 1989).
The carbohydrate metabolism of the dog is more fluctuating than that of the human. A degree of diabetic control as obtained in humans seems out of view. For the practical dog owner only the good clinical response matters.

This study shows that it is possible to obtain a good control of the carbohydrate metabolism in the diabetic dog with 2 injections per day of isophane insulin with a low frequency of hypoglycemic episodes. The long term success is to a great extent influenced by the degree and severity of concominant diseases.

\section{Acknowledgements}

I am in great debt to my colleagues Bjarne Bidstrup and Göran Johnelius for their tireless efforts to get the studies established and conducted. Furthermore, great many thanks to my veterinary colleagues in the small animal clinics in Gentofte, Greve, Göteborg, Hälsingborg, Jönköping, Kalmar, Karlslunde, København, Lyngby, Odense, Skovlunde, Uppsala og Värløse for their enthusiastic and valuable support which is the major reason why the studies succeeded at all.

\section{References}

Chastain CB, Nichols, CE: Current concepts on the control of diabetes mellitus. Vet. Clin. North Amer. Small Animal Pract. 1984, 14, 860-72.

Feldman EC, Nelson RW: Canine and feline endocrinology and reproduction. W.B. Saunders, Philadelphia. 1987, pp. 229-273. 
Goeders LA, Esposito LA, Peterson ME: Absorption kinetics of regular and isophane (NPH) insulin in the normal dog. Domestic Anim. Endocrin. 1987, 4, 43-50.

Gordon RN: The clinical management of diabetes mellitus in dogs and cats. Austr. vet. J. 1967, 43, 568-74.

Holm B: Insulinbehandling av hund - något för dig? (Insulin treatment of dogs - a challenge for you?). Svensk Veterinärtidn.1989, 41, 393-399.

Lilley R: Diabetes mellitus in small animals. Austr. vet. Practit. 1988, 18, 22-30.

Lorenzen FL: Estimation of the dynamic and kinetic profile of isophane insulin (Protaphan ${ }^{\circledR}$ ) in normal dogs. Internal Report, 1987, Study no. 14887. pp. 1-15.

Milne EM: Diabetes mellitus : An update. J. Small Anim. Pract. 1987, 28, 727-36.

Milne E: Diabetes mellitus. In Practice. 1989, 105109.

Nelson RW: Disorder of the glucose metabolism in the dog -1 : Diabetes mellitus. Vet. Med. 1985a, 27-36.

Nelson RW: Disorders of glucose metabolism in the dog - 2: Complications of insulin therapy and diabetes mellitus. Vet. Med. 1985b, 57-70.

Nelson RW: Disorders of the endocrine pancreas. In: Ettinger S (Ed): Diseases of the dog and cat. 3rd ed.. Saunders, Philadelphia 1989, pp 1676-1720.

Schaer M: Insulin treatment for the diabetic dog and cat. The Comp. Cont. Educ. 1983, 5, 579-88.

\section{Sammendrag}

Anvendelse af isophaninsulin til behandling af diabetes mellitus hos hund.

I dette studie indgik fra 13 smådyrsklinikker i Dan- mark og Sverige 54 hunde med diabetes mellitus. Diagnosen var i det enkelte tilfælde sikret med en fyldig anamnese samt kliniske og laboratoriemæssige unders $\varnothing$ gelser. Efter passende instruktion gav ejerne hundene injektioner af isophaninsulin morgen og aften, hvorefter hundene fodredes med et færdigfremstillet eller hjemmelavet fiberrigt foder. Klinikdyrlægerne unders $\varnothing$ gte de behandlede hunde 5 gange eller mere i den efterfølgende 90 -dages periode, fortrinsvis om morgenen inden injektion og foderindtagelse. Hos alle 54 hunde begyndte de kliniske symptomer at forsvinde efter få dages insulinbehandling, og 54\% af hundene var klinisk normale efter 8 dage. Efter en måneds behandling var $96 \%$ af hundene normaliserede af behandlingen. Samtidig blev blodglukoseniveauerne normaliserede hos $64 \%$ af hundene inden for 14 dage og hos yderligere $21 \%$ inden for 1 måned. Uringlukoseværdierne blev normaliserede hos $64 \%$ af hundene inden for 14 dage og yderligere $19 \%$ inden for 1 måned.

Ved fors $\emptyset$ gets afslutning var 48 af de oprindelige 54 diabetiske hunde fortsat $\mathrm{i}$ behandling og klinisk sunde og uden symptomer på diabetes mellitus. Den anvendte 2-gange-i-døgnet gennemsnitsdosis var for store hunde 0,44 enh. pr. kg, for små hunde 0,79 . Seks hunde var blevet aflivet i fors $\emptyset$ gsperioden af forskellige årsager. En ejer havde problemer med at give injektionerne. En anden ejer blev indlagt på hospital og kunne ikke få hunden passet. En hund udviklede en intraktabel mammacancer, en blev bidsk og to udviklede svær katarakt. Fire hunde havde 1 eller 2 gange vist symptomer på hypoglykæmi, som forsvandt hurtigt efter passende justeringer af insulindosis, fodermængde og motionsrytme.

Det kan konkluderes, at isophaninsulin er et velegnet præparat til diabetiske hunde $\mathrm{i}$ et 2-gange-idøgnet behandlingsprogram.

(Received April 1, 1992; accepted May 22, 1992).

Reprints may be requested from: F. Hjort Lorenzen, Pharmaceutical Division, NovoNordisk A/S, Novo Alle, DK-2880 Bagsværd, Denmark. 